\title{
Pengaruh Kompetensi, Dan Kompensasi Terhadap Motivasi Serta Dampaknya Terhadap Kinerja Karyawan Pada STMIK Rosma Karawang
}

\author{
Yeny Rostiani \\ STMIK Rosma Karawang, Komputerisasi Akuntansi \\ yenirostiani90@yahoo.com
}

\begin{abstract}
ABSTRAK
Tujuan penelitian ini adalah untuk memperoleh bukti-bukti empirik dan menemukan kejelasan fenomena serta kesimpulan tentang pengaruh kompetensi dan kompensasi terhadap motivasi serta dampaknya pada kinerja karyawan di STMIK Rosma Karawang.

Penelitian dilakukan dengan menggunakan metode analisis deskriptif dan verifikatif, yaitu; mengumpulkan, menyajikan, menganalisis dan melakukan pengujian hipotesis, serta membuat kesimpulan dan saran. Penelitian ini juga bermaksud memberikan rekomendasi bagaiman meningkatkan kinerja karyawan di STMIK Rosma Karawang. Data dikumpulkan melalui penyebaran kuisioner terhadap 75 orang, selain kuisioner data juga dikumpulkan melalui wawancara singkat. Pengukuran keandalan butir pertanyaan dengan sekali menyebarkan kuisioner pada responden, kemudian hasil skornya diukur korelasinya antara skor jawaban pada butir pertanyaan yang sama dengan bantuan komputer Statistical Product and Service Solution (SPSS), dengan fasilitas cronbach alpa (a), suatu variabel dikatakann reliabel jika memberikan nilai cronbach alpa $>0,60$. Hasil penelitian ini menunjukan bahwa secara simultan Kompetensi dan kompensasi berpengaruh terhadap motivasi. pengaruh kompensasi lebih besar terhadap motivasi daripada pengaruh kompetensi terhadap motivasi. Hal ini mengindikasikan bahwa pengaruh kompensasi lebih dominan daripada pengaruh kompetensi terhadap motivasi.
\end{abstract}

Kata kunci : Kompetensi, Kompensasi, Motivasi, Kinerja Karyawan.

\begin{abstract}
The purpose of this study is to obtain empirical evidence and find clarity of phenomena and conclusions about the influence of competence and compensation on motivation and its impact on employee performance in STMIK Rosma Karawang.

The research was conducted by using descriptive and verification method, namely; collect, present, analyze and perform hypothesis testing, as well as make conclusions and suggestions. This study also intends to provide recommendations how to improve employee performance in STMIK Rosma Karawang. Data were collected through questionnaires distributed to 75 people, in addition to the questionnaire data were also collected through short interviews. Measurement reliability of the question items by once distributing the questionnaire to the respondent, then the result of the score is measured the correlation between the answer score in the same question item with the aid of Statistical Product and Service Solution (SPSS) computer, with cronbach alpa (a) facility, a variable is said to be reliable if the value of cronbach is > 0.60. The results of this study show that simultaneously Competence and compensation affect the motivation. the effect of greater compensation on motivation rather than the influence of competence on motivation. This indicates that the effect of compensation is more dominant than the influence of competence on motivation.
\end{abstract}

Keywords: Competence, Compensation, Motivation, Employee Performance. 


\section{PENDAHULUAN}

Karyawan yang memiliki kompetensi dalam suatu organisasi akan menjadi keunggulan sekaligus sebagai pendukung dalam organisasi sebagai daya saing dalam memasuki era globalisasi dan menghadapi lingkungan usaha serta kondisi sosial masyarakat yang mengalami perubahan dengan cepat.

Berdasarkan hasil evaluasi kinerja pada Sekolah Tinggi Manajemen Informatika dan Komputer (STMIK) Rosma Karawang tahun 2015 yang dikategorikan pada (1) aspek loyalitas sebesar $27.8 \%$, (2) kemampuan dalam bekerja, sebesar $28.6 \%$, (3) untuk aspek penilaian sikap didapat hasil sebesar $26.8 \%$, dan (4) aspek Inisiatif kerja menunjukan angka sebesar $16.7 \%$. Berdasarkan hasil dari evaluasi kinerja yang telah dilaksanakan tersebut dapat disimpulkan bahwa motif karyawan dalam hal inisiatif kerja masih tergolong rendah, oleh karena itu kondisi kerja di STMIK Rosma masih perlu mendapat perhatian dan dievalusi secara terus menerus, dalam upaya meningkatkan kualitas proses belajar dan mengajar guna menghasilkan kualitas lulusan yang unggul dan kompetitif, mengingat keberhasilan suatu institusi dalam menyelenggarakan pendidikan bergantung kepada kinerja seluruh karyawannya agar bekerja secara optimal, efektif dan efisien.

Berdasarkan hasil wawancara awal dan observasi yang penulis lakukan saat ini kinerja karyawan yang ada di STMIK Rosma Karawang perlu ada perbaikan karena masih belum optimal, juga harus ada peningkatan dalam hal komunikasi diantara para karyawan agar tersampaikan secara baik dan merata kepada seluruh karyawan, peraturan disiplin kerja dan keteraturan kerja sudah dituangkan dalam prosedur-prosedur kerja yang lengkap, namun demikian karyawan masih belum mematuhi aturan-aturan ataupun prosuder yang telah ditetapkan seperti halnya karyawan yang terlambat datang di kantor, terlambat masuk setelah jam makan siang. Hal ini mengindikasikan dari ketidakdisiplinan karyawan dalam mematuhi peraturan yang telah ditetapkan.

Menurut Harimisa (2013:2144), menyatakan dalam penelitiannya bahwa "pemberian motivasi kepada karyawan dapat dilakukan dengan berbagai cara yaitu paksaaan dan hukuman, imbalan, penghargaan dan pujian". Oleh karenanya dengan diberikannya motivasi kepada para karyawan dapat menyebabkan karyawan memperbaiki dan meningkatkan kinerja sehingga produktivitas kerja pun dapat meningkat.
Kompensasi merupakan hal yang penting, yaitu sebagai dorongan motivasi karyawan dalam bekerja. Hal ini berarti karyawan menggunakan pengetahuan, keterampilan, tenaga dan waktunya bukan semata-mata ingin membaktikan atau mengabdikan diri pada perusahaan, tetapi ada tujuan lain yaitu, mengharapkan imbalan atau balas jasa, atas hasil kerja yang telah diberikan.

Menghadapi persaingan yang semakin kompetitif diantara berbagai perguruan tinggi swasta yang ada saat ini, STMIK Rosma tetap menekankan pada komitmen untuk menyelenggarakan pendidikan berkualitas, dengan berbasis Informasi Teknologi (IT), oleh sebab itu pihak-pihak yang terkait baik pimpinan, pengelola maupun karyawan, harus bekerja sama untuk tercapainya tujuan organisasi tersebut, sehingga dapat menghasilkan kualitas lulusan yang unggul dan kompetitif. Agar tujuan tersebut dapat tercapai harus didukung oleh adanya sumber daya manusis yang handal dan professional serta tersediannya sarana dan prasarana yang mendukung sehingga karyawan, dosen serta mahasiswa mendapatkan kenyamanan dalam melaksanakan kegiatan belajar mengajar dan bekerja.

Upaya yang telah dilakukan oleh STMIK Rosma saat ini dalam hal peningkatan kompetensi sumber daya manusianya dari bidang pendidikan adalah dengan memberikan beasiswa kepada karyawan dan dosen untuk melanjutkan pendidikan ke jenjang Magister (S-2), guna mendukung kegiatan perkuliahan. Pemberian dan peningkatan kualitas sumber daya manusia melalui program pelatihan akan berdampak pada peningkatan pengetahuan, keterampilan dan pengalaman ataupun perubahan sikap yang dimiliki oleh individu yang akhirnya semua itu akan berdampak pada kinerja.

\section{Perumusan Masalah}

Berdasarkan latar belakang masalah sebagaimana yang diuraikan diatas, maka dirumuskan permasalahan sebagai berikut:

1. Bagaimana kompetensi karyawan di STMIK Rosma Karawang.

2. Bagaimana kompensasi karyawan di STMIK Rosma Karawang.

3. Bagaimana motivasi karyawan di STMIK Rosma Karawang.

4. Bagaimana kinerja karyawan di STMIK Rosma Karawang.

5. Seberapa besar pengaruh kompetensi terhadap motivasi di STMIK Rosma Karawang.

6. Seberapa besar pengaruh kompensasi terhadap motivasi di STMIK Rosma Karawang. 
7. Seberapa besar pengaruh simultan kompetensi dan kompensasi terhadap motivasi di STMIK Rosma Karawang.

8. Seberapa besar pengaruh motivasi terhadap kinerja karyawan di STMIK Rosma Karawang.

\section{TINJAUAN PUSTAKA}

\section{Manajemen Sumber Daya Manusia}

Menurut Heidjrachman dan Suad Husnan (2000:5), "manajemen sumber daya manusia adalah perencanaan, pengorganisasian, pengarahan, pengawasan, dari pengadaan, pengembangan, pemberian kompensasi pengintegrasian, dan pemeliharaan tenaga kerja dalam maksud untuk membantu mencapai tujuan-tujuan perusahaan, individu, dan masyarakat".

Menurut Sedarmayanti

(2007:13),

"Manajemen Sumber Daya Manusia adalah kebijakan dan praktik menentukan aspek "manusia" atau sumber daya manusia dalam posisi manajemen, termasuk merekrut, menyaring, melatih, memberi penghargaan dan penilaian".

\section{Kompetensi}

Menurut Spencer \& Spencer dalam Moeheriono (2010:3), "kompetensi adalah karakteristik yang mendasari seseorang berkaitan dengan efektivitas kinerja individu dalam pekerjaanya atau karakteristik dasar individu yang memiliki hubungan kausal atau sebagai sebab akibat dengan kriteria yang dijadikan acuan, efektif atau berkinerja prima atau superiaor di tempat kerja atau pada situasi tertentu".

Menurut Mondy (2008:261), "kompetensi adalah sekumpulan luas pengetahuan, keterampilan, sifat dan perilaku yang bisa bersifat teknis, berkaitan dengan keterampilan antar pribadi atau berorientasi bisnis".

\section{Kompensasi}

Menurut Tubagus (2015:163), "kompensasi atau lebih popular dengan istilah balas jasa merupakan hasil dari kerja seseorang yang berupa pembayaran dalam bentuk uang yang akan digunakan untuk memenuhi kebutuhan hidupnya, baik kebutuhan primer maupun kebutuhan sekunder". Istilah kompensasi dikenal pada abad $\mathrm{ke}-4$, yang berasal dari bahasa latin compensationem yang artinya kesetaraan (balancing).

Menurut Sastrohadiwiryo (2002:195), "kompensasi didefinisikan sebagai balas jasa yang diberikan oleh perusahaan kepada tenaga kerja, karena tenaga kerja memberikan sumbangan tenaga dan pikiran demi kemajuan perusahaan guna mencapai tujuan yang telah ditetapkan baik dalam jangka pendek maupun jangka panjang".

\section{Motivasi}

Menurut Hamzah B. Uno (2006:5), menyatakan "bahwa motivasi sebagai kekuatan yang berada dalam diri individu, yang menyebabkan individu tersebut bertindak atau berbuat, Motivasi seseorang tergantung kepada kekuatan motifnya".

Motif dengan kekuatan yang sangat besarlah yang akan menentukan perilaku seseorang, dan sosok yang paling berpengaruh terhadap peningkatan motivasi perusahaan adalah pimpinan, seorang pimpinan harus memahami teori motivasi agar dapat mengidentifikasi apa yang menjadi motif karyawan bekerja dan mengapa karyawan berprestasi tinggi.

Menurut Alma (2007:88-89), "motif yang kuat ini seringkali berkurang manakala telah mencapai kepuasan ataupun karena menemui kegagalan. Jadi kekuatan motif ini dapat berubah karena:

1. Terpuaskannya kebutuhan

Bila kebutuhan telah terpuaskan maka motif akan berkurang, dan beralih kepada kebutuhan lain dan seterusnya.

2. Karena adanya hambatan, maka orang akan mencoba mengalihkan motifnya ke arah lain

\section{Kinerja}

Kinerja selalu terkait dengan ukuran-ukuran serta parameter yang dijadikan acuan oleh suatu organisasi untuk penilaian karyawannya.

Menurut Soeprihanto (2009:23), "mengatakan dalam melakukan penilaian terhadap pelaksanaan pekerjaan atau prestasi kerja seorang karyawan harus memiliki pedoman dan dasar-dasar penilaian". Pedoman dan dasar-dasar penilaian tersebut dapat dibedakan dalam aspek-aspek penilaian. Yang dimaksud dengan aspek penilaian disini adalah hal-hal yang pada dasarnya merupakan sifat-sifat atau ciri-ciri yang dapat menunjukan bahwa pelaksanaan suatu pekerjaan tertentu dapat bejalan dengan lancar dan berhasil dengan baik, atau dengan kata lain ciri-ciri dari pelaksanaan pekerja yang berhasil digunakan kembali untuk menilai setiap pelaksanaan pekerjaan yang bersangkutan secara rutin.

\section{HIPOTESIS PENELITIAN}

Berdasarkan identifikasi masalah dan kerangka pemikiran yang telah dikemukakan maka dapat dirumuskan hipotesis sebagai berikut: 
1. Terdapat pengaruh kompetensi terhadap motivasi di STMIK Rosma Karawang

2. Terdapat pengaruh kompensasi terhadap motivasi di STMIK Rosma Karawang

3. Terdapat pengaruh secara parsial dan simultan kompetensi dan kompensasi terhadap motivasi di STMIK Rosma Karawang

4. Terdapat pengaruh motivasi terhadap kinerja karyawan di STMIK Rosma Karawang

\section{METODE PENELITIAN}

Penelitian ini menggunakan metode analisis data deskriptif dan verifikatif. Metode deskriptif adalah metode penelitian yang bertujuan untuk menggambarkan, menjelaskan keadaan yang ada di perusahaan berdasarkan fakta dan data yang dikumpulkan kemudian disusun secara sistematis, metode ini digunakan untuk menjawab rumusan masalah yaitu bagaimana kompetensi, bagaimana kompensasi, bagaimana motivasi, serta bagaimana kinerja karyawan pada STMIK Rosma Karawang. Metode verifikatif digunakan untuk menjawab rumusan masalah seberapa pengaruhkah kompetensi dan kompensasi terhadap motivasi baik secara parsial maupun simultan serta pengaruh motivasi terhadap kinerja karyawan pada STMIK Rosma Karawang.

Sampel dalam penelitian ini berjumlah 75 orang berasal dari populasi karyawan STMIK Rosma Karawang orang yang terdiri dari struktural, dosen tetap, dosen tidak tetap, staff dan bagian umum. Menurut Riduwan (2004:56), "sampel adalah bagian dari populasi yang mempunyai ciriciri atau keadaan tertentu yang akan diteliti”.

Jika peneliti mempunyai beberapa ratus subyek dalam populasi, mereka dapat menentukan kurang lebih 25\%-30\% dari jumlah subyek tersebut. Jika jumlah anggota subyek dalam populasi hanya meliputi 100 hingga 150 orang dan dalam pengumpulan data, peneliti menggunakan angket/kuisioner, sebaiknya subyek sejumlah itu diambil seluruhnya. Sehingga dapat dikatakan sebagai penelitian sensus".

Dengan penetapan sampel adalah :

$$
\mathbf{n}=\mathbf{N}
$$

Keterangan :

$\mathrm{N}=$ Jumlah populasi

$\mathrm{n}=$ Jumlah sampel

Berdasarkan rumus tersebut, jumlah sampel penelitian sama dengan populasi karyawan STMIK Rosma yaitu sebanyak 75 orang. Adapun teknik pengumpulan data yang digunakan dalam penelitian ini adalah melalui pengamatan, wawancara dan penggunaan kuisioner yang dikuantifikasikan dengan menggunakan skala Likert dengan 5 (lima) kategori jawaban untuk setiap pertanyaan yang diajukan kepada responden.

\section{Metode Pengujian Keabsahan Data}

\section{Uji Validitas}

Uji Validitas adalah suatu data dapat dipercaya kebenarannya sesuai dengan kenyataan. Menurut Sugiyono (2009:172), "valid berarti instrumen tersebut dapat digunakan untuk mengukur apa yang seharusnya diukur". Syarat minimum dianggap memenuhi syarat adalah jika $r$ $=0.3$. Jika korelasi antara butir dengan skor total kurang dari 0.3, maka butir dalam instrumen tersebut dinyatakan tidak valid. Untuk mencari nilai korelasinya penulis menggunakan rumus Pearson Product moment sebagai berikut:

$$
r_{x y}=\frac{N\left(\sum X_{1} Y_{1}\right)-\left(\sum X_{1}\right)\left(\sum Y_{1}\right)}{\sqrt{\left\{n\left(\sum X_{1}^{2}\right)-\left(\sum X_{1}\right)^{2}\right\}\left\{n\left(Y_{1}^{2}\right)-\left(\sum Y_{1}\right)^{2}\right\}}}
$$

Dimana :

$\mathrm{r}_{\mathrm{xy}}=$ Korelasi antara variabel $\mathrm{x}$ dan $\mathrm{y}$

$\mathrm{n}=$ Jumlah sampel

$\mathrm{X}=$ Skor per item

$\mathrm{Y}=$ Total skor

Dikatakan valid menurut Santoso (2000), jika $\mathrm{r}_{\text {hitung }}$ $>\mathrm{r}_{\text {table, }}$ maka instrument penelitian :

\section{Uji Realibilitas}

Menurut Amalia Nur Chamsah (2011), "untuk mengetahui kehandalan suatu alat ukur diperlukan uji reliabilitas, yang berfungsi sebagai alat untuk mengukur kuisioner yang merupakan suatu indikator dari variabel/konstruk". Suatu kuisioner dikatakan reliabel apabila jawaban seseorang terhadap pertanyaan adalah konsisten atau stabil dari waktu ke waktu.

\section{Uji Normalitas}

Menurut Priyatno (2009:40), “untuk melakukan analisis parametrik seperti independent sampel t test, korelasi bivatriate, regresi, analisis jalur, dan sebagainya, syaratnya adalah data harus terdistribusi normal". Uji normalitas dilakukan dengan menggunakan uji Kolmogorov-Smirnov. Kriteria pengujian adalah jika signifikasn $>0,05$ $(a>0,05)$, maka data berdistribusi normal, 
sedangkan jika signifikansi $<0,05(a<0,05)$, maka data tidak terdistribusi normal.

\section{Skala Pengukuran}

Skala Likert menurut Husein Umar (2005), "yang mengutip pendapat kinner adalah berhubungan dengan pernyataan sikap seseorang terhadap sesuatu". Responden diminta mengisi pernyataan dalam skala ordinal berbentuk verbal dalam jumlah kategori tertentu. Dengan menggunakan skala likert, maka variabel yang akan diukur dijabarkan menjadi dimensi, kemudian dimensi dijabarkan menjadi sub variabel dan kemudian sub variabel dijabarkan lagi ini dapat dijadikan titik tolak untuk membuat instrument (kuesioner) yang dapat berupa pernyataan atau pertanyaan. Jawaban setiap Item instrument mempunyai gradasi dari sangat ositif sampai sangat negatif.

\section{Transformasi Data}

Data variabel yang terkumpul melalui kuesioner dalam penelitian ini berbentuk data ordinal, sedangkan untuk menganalisis dengan analisis jalur diperlukan data dengan ukuran paling tidak berskala interval. Oleh karena itu, data dinaikan menjadi data interval dengan method of succesive interval (MSI). Merubah data ordinal menjadi skala interval berurutan (Method of Successive Interval). Tahapannya :

1. Menentukan frekuensi setiap respon

2. Menentukan proporsi setiap respon dengan membagi frekuensi dengan jumlah sampel

3. Menjumlahkan proporsi secara berurutan untuk setiap respon sehingga diperoleh proporsi kumulatif

4. Menentukan $\mathrm{Z}$ untuk masing-masing proporsi kumulatif yang dianggap menyebar mengikuti sebaran normal baku. Nilai Z diperoleh dari Tabel Distribusi Normal Baku.

5. Menghitung nilai densitas dari nilai $Z$ yang diperoleh dengan cara memasukkan nilai $\mathrm{Z}$

Tersebut ke dalam fungsi densitas normal baku sebagai berikut :

$$
f(z)=\frac{1}{\sqrt{2 \pi}} \exp \left(-\frac{1}{2} z^{2}\right)
$$

6. Menghitung Scale Value (SV) untuk masingmasing respon

$$
S V=\frac{\text { (density at lower l imiț - (idensity at upper limit) }}{\text { (areaunder offerl limit) - (underlowerl limit) }}
$$

7. Mengubah Scale Value (SV) terkecil (nilai negatif yang terbesar) menjadi sama dengan satu 1 dan mentransformasikan masing-masing skala menurut perubahan skala terkecil sehingga diperoleh Transformed Scale Value (TSV). Mentransformasikan nilai skala dengan menggunakan rumus

$$
Y=S V+|S V \min |
$$

\section{Analisis Verifikatif}

\section{Analisis Korelasi Produk Moment}

Penelitian ini menggunakan analisis korelasi produk moment (correlation product moment) adalah salah satu pendekatan untuk mengetahui keeratan antara satu variabel dengan variabel lainya, dengan rumus:

$$
\frac{n(\Sigma X Y)-(\Sigma X \Sigma Y)}{\sqrt{\left(n \Sigma X^{2}-(\Sigma X)^{2}\right)\left(n \Sigma Y^{2}-(\Sigma Y)^{2}\right)}}
$$

Dimana :

$\mathrm{r}=$ Koefisien korelasi

$\mathrm{n}=$ Jumlah sampel

$X=$ Variabel independen

$\mathrm{Y}=$ Variabel dependen

Sumber : Sugiyono (2013:228)

\section{Teknik Analisis Jalur (Path Analysis)}

Analisis jalur (path analysis) digunakan untuk menganalisis pola hubungan antar variabel dengan tujuan untuk mengetahui pengaruh langsung maupun tidak langsung seperangkat variabel bebas (eksogen) terhadap variabel terikat (endogen). Langkah-langkah menguji analisis jalur:

1. Merumuskan hipotesis

2. Merumuskan persamaan struktural $Z=\rho \mathrm{yx}_{1} \mathrm{X}_{1}+\rho \mathrm{yx}_{2} \mathrm{X}_{2}+\rho \mathrm{zy} \mathrm{Y}+\varepsilon_{1+} \varepsilon_{2}$

3. Perhitungan koefisien jalur yang didasarkan pada koefisien regresi

4. Menggambarkan diagram jalur lengkap, menentukan sub-sub strukturnya dan merumuskan persamaan strukturalnya yang sesuai dengan hipotesa yang diajukan.

5. Menghitung koefisien regresi untuk struktur yang telah dirumuskan dengan menggunakan persamaan regresi ganda

6. Menghitung koefisien jalur secara simultan (keseluruhan), melalui menguji secara keseluruhan hipotesis statistik yang dirumuskan sebagai berikut :

$$
\begin{aligned}
& \mathrm{H}_{0}: \rho \mathrm{yx}_{1}=\rho \mathrm{yx}_{2}=0 \\
& \mathrm{Ha}: \rho \mathrm{yx}_{1}=\rho \mathrm{yx}_{2} \neq 0
\end{aligned}
$$


Adapun rancangan analisis untuk penelitian ini dapat dilihat pada gambar 3.1

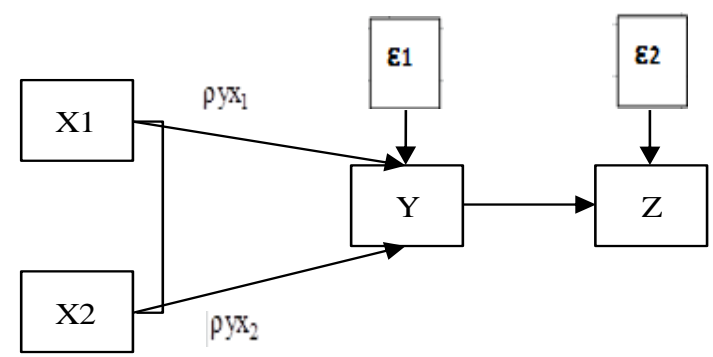

Gambar 1, Analisis Jalur

\section{Uji Hipotesis}

Uji hipotesis untuk mendeskripsikan ketiga variabel penelitian secara statistik adalah sebagai berikut:

Hipotesis 1: Terdapat pengaruh kompetensi terhadap motivasi pada STMIK Rosma Karawang.

H0 : $\rho y x 1=0$ (tidak ada pengaruh)

H1 : $\rho y x 1 \neq 0$ (ada pengaruh)

Hipotesis 2: Terdapat pengaruh kompensasi terhadap motivasi pada STMIK Rosma Karawang

$\mathrm{H}_{0}: \rho \mathrm{yx}_{2}=0$ (tidak ada pengaruh)

$\mathrm{H}_{1}: \rho \mathrm{yx}_{2} \neq 0$ (ada pengaruh)

Hipotesis 3: Terdapat pengaruh secara parsial dan simultan kompetensi dan kompensasi terhadap motivasi pada STMIK Rosma Karawang.

$\mathrm{H}_{0}: \rho \mathrm{yx}_{1} ; \rho \mathrm{yx}_{2}=0$ (tidak ada pengaruh

$\mathrm{H}_{1}: \rho \mathrm{yx}_{1} ; \rho \mathrm{yx}_{2} \neq 0$ (ada pengaruh)

Hipotesis 4: Terdapat pengaruh motivasi terhadap kinerja karyawan pada STMIK Rosma Karawang

$\mathrm{H}_{0}: \rho Z_{Y}=0$ (tidak ada pengaruh)

$\mathrm{H}_{1}: \rho Z_{Y} \neq 0$ (ada pengaruh)

\section{HASIL PENELITIAN DAN PEMBAHASAN}

\section{Uji Validitas}

Berdasarkan uji validitas untuk variable kompetensi, kompensasi, motivasi dan kinerja mempunyai koefisien korelasi lebih besar dari pada $r$ kritis yaitu 0,300 yang berarti semua item pertanyaan kuisioner untuk semua variable tersebut valid.

\section{Uji Reliabilitas}

Teknik pengujian reliabilitas menggunakan koefisien alpha cronbach dengan taraf nyata 5\% $(0,05)$. Untuk menilai reliabel tidaknya instrumen dilakukan dengan mengkonsultasikan hasil perhitungan alpha cronbach dengan angka tabel $\mathrm{r}$ hitung. Apabila cronbach alpha $(\alpha)>0,600$ maka reliabilitas pertanyaan bisa diterima.
Berdasarkan hasil uji reliabilitas untuk kuisioner masing-masing variabel dapat penelitian dinyatakan reliabel.

\section{Uji Normalitas}

Uji normalitas digunakan untuk mengetahui apakah suatu data mengikuti sebaran normal atau tidak, untuk mengetahui apakah data tersebut mengikuti sebaran normal dapat dilakukan dengan metode Kolmogorov-Smirnov. Hasil perhitungan data menunjukkan bahwa semua variabel mengikuti distribusi normal dengan $\mathrm{p}$-value $>\alpha$ (Sudjana, 2005: 273). Maka berdasarkan uji normalitas, semua variabel mengikuti sebaran data normal karena nilai $\rho$ value $>0.05$.

\section{Analisis Jalur}

Berdasarkan pengolahan data dengan menggunakan analisis jalur, untuk masing-masing variabel bebas terhadap variabel terikat bahwa besaran derajat asosiatif atau koefisien jalur variabel Kompensasi $\left(\mathrm{X}_{2}\right)$ lebih tinggi dibandingkan dengan variabel Kompetensi $\left(\mathrm{X}_{1}\right)$ artinya Kompensasi $\left(\mathrm{X}_{2}\right)$ lebih berpengaruh terhadap Motivasi (Y) pada STMIK Rosma Karawang dibandingkan variabel Kompetensi $\left(\mathrm{X}_{1}\right)$. Sehingga untuk persamaan jalurnya, yaitu :

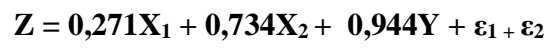

Mengetahui total pengaruh dari variabel Kompetensi $\left(\mathrm{X}_{1}\right)$ dan Kompetensi $\left(\mathrm{X}_{2}\right)$ terhadap Motivasi (Y) dinyatakan oleh besaran koefisien determinasi $\left(\mathrm{R}^{2}\right)$. Nilai Koefisien determinasi didapatkan sebesar 0,980 $(98,0 \%)$, hal ini berarti Kompetensi $\left(\mathrm{X}_{1}\right)$ dan Kompensasi $\left(\mathrm{X}_{2}\right)$ memiliki kontribusi terhadap Motivasi (Y) sebesar 98,0\% sedangkan sisanya 2,0\% merupakan kontribusi variabel lain $(\varepsilon)$ yang tidak diteliti. Sedangkan koefisien determinasi Motivasi (Y) terhadap Kinerja (Z) sebesar 0,891 (89.1\%), berarti ini berarti Motivasi (Y) memiliki kontribusi terhadap Kinerja sebesar $88,9 \%$ sedangkan sisanya $11,1 \%$ merupakan kontribusi variabel lain $(\varepsilon)$ yang tidak diteliti.

\section{Uji Hipotesis}

Pengaruh Kompetensi $\left(\mathrm{X}_{1}\right)$ secara parsial terhadap Kinerja Karyawan (Y), dengan tingkat signifikansi $(\alpha)=5 \%$ dan degree of freedom $(\mathrm{df})=$ $(n-2)=75-2=73$ sehingga diperoleh $\mathrm{t}$ tabel $=$ 1,666. Ini berarti nilai Sig. $(0,000<\alpha(0,05)$ dan $t$ hitung $(6,291)>t$ tabel $(1,666)$ sehingga Ho ditolak. Dengan demikian dapat disimpulkan bahwa 
terdapat pengaruh parsial Kompetensi terhadap Motivasi pada STMIK Rosma Karawang.

Pengaruh Kompensasi $\left(\mathrm{X}_{2}\right)$ secara parsial terhadap Motivasi (Y), dengan tingkat signifikansi $(\alpha)=5 \%$ dan degree of freedom $(\mathrm{df})=(\mathrm{n}-2)=75$ $-2=73$ sehingga diperoleh $\mathrm{t}$ tabel $=1,666$. Berdasarkan hasil pengolahan data menunjukan nilai Sig. $(0,00)<\alpha(0,05)$ dan $\mathrm{t}$ hitung $(17,048)>\mathrm{t}$ tabel $(1,666)$ sehingga dapat di simpulkan bahwa Ho ditolak. Hal ini menunjukkan bahwa terdapat pengaruh secara parsial kompensasi terhadap Motivasi pada STMIK Rosma Karawang.

Pengaruh Kompetensi $\left(\mathrm{X}_{1}\right)$ dan Kompensasi $\left(\mathrm{X}_{2}\right)$ secara simultan terhadap Motivasi (Y), dengan tingkat signifikansi $(\alpha)=5 \%$ dan degree of freedom $(\mathrm{df})=(\mathrm{n}-2)=75-2=73$ sehingga diperoleh $\mathrm{f}$ tabel $=3,12$. Hasil yang didapat menunjukan nilai Sig. $(0,000)<\alpha(0,05)$ dan $\mathrm{f}$ hitung $(1825,255)>\mathrm{f}$ tabel $(3,12)$ sehingga Ho ditolak. Dengan demikian dapat disimpulkan bahwa terdapat pengaruh simultan dari Kompetensi dan Kompensasi terhadap Motivasi pada STaMIK Rosma Karawang.

Pengaruh Kompensasi $\left(\mathrm{X}_{2}\right)$ secara parsial terhadap Motivasi (Y), dengan tingkat signifikansi $(\alpha)=5 \%$ dan degree of freedom $(\mathrm{df})=(\mathrm{n}-2)=75$ $-2=73$ sehingga diperoleh $\mathrm{t}$ tabel $=1,666$. menunjukan nilai Sig. $(0,00)<\alpha(0,05)$ dan t hitung $(24,370)>\mathrm{t}$ tabel $(1,666)$ sehingga dapat di simpulkan bahwa Ho ditolak. Hal ini menunjukkan bahwa terdapat pengaruh Motivasi terhadap Kinerja Karyawan pada STMIK Rosma Karawang.

\section{KESIMPULAN DAN SARAN}

\section{Kesimpulan}

Mengacu pada hasil penelitian dan pembahasan hasil deskriptif dan verifikatif, dapat dibuatkan beberapa asebagai berikut

1. Variabel kompetensi berada pada skala cukup setuju, artinya kompetensi yang ada memenuhi standar yang telah ditetapkan.

2. Variabel kompensasi berada pada skala cukup setuju, berarti kompensasi yang diberikan cukup baik dan sesuai dengan pedoman yang telah ditetapkan organisasi.

3. Variabel motivasi pada STMIK Rosma Karawang berada pada skala cukup setuju, artinya motivasi yang dimiliki oleh karyawan sudah cukup baik

4. Kinerja karyawan pada STMIK Rosma Karawang berada pada skala cukup setuju, kinerja karyawan sudah cukup dilaksanakan dengan baik sesuai peraturan yang diberlakukan oleh organisasi
5. Pengaruh Kompetensi terhadap Motivasi secara parsial lebih kecil daripada pengaruh kompensasi terhadap motivasi

6. Pengaruh Kompensasi terhadap Motivasi secara parsial lebih besar terhadap motivasi daripada pengaruh kompetensi terhadap motivasi. Hal ini mengindikasikan bahwa pengaruh kompensasi lebih dominan daripada pengaruh kompetensi terhadap motivasi.

7. Pengaruh Kompetensi dan Kompensasi secara simultan terhadap motivasi di sebesar 98,0\%. Hal ini mengindikasikan masih ada $2 \%$ variabel lain yang mempengaruhi motivasi pada STMIK Rosma Karawang.

8. Pengaruh Motivasi terhadap Kinerja Karyawan di STMIK Rosma Karawang sebesar 89,1\%. Hal ini mengindikasikan masih ada $11,9 \%$ variabel lain yang mempengaruhi kinerja karyawan di STMIK Rosma Karawang.

\section{Saran}

Berdasarkan hasil penelitian dan pembahasan, penulis dapat memberikan saran sebagai berikut :

1. Kompetensi yang terdapat pada STMIK Rosma Karawang, sudah cukup baik dan agar tetap mempertahankan dan meningkatkannya lagi kearah yang lebih baik.

2. Kompensasi yang sudah diberikan selama ini cukup baik, artinya sesuai dengan kemampuan institusi, tetapi institusi agar memperbaiki halhal yang masih kurang seperti adanya kenaikan gaji yang diberikan setiap tahun, pemberian tunjangan, dan komisi, dari sisi kompensasi non finansial selalu memberikan kesempatan untuk berkembang kepada seluruh karyawannya, meliputi pendidikan dan pelatihan, pemberian penghargaan atas kinerja, pembagian kerja, dan kondisi kerja yang mendukung.

3. STMIK Rosma Karawang, diharapkan mampu mempertahankan motivasi yang telah baik dan meningkatkan nya kembali

4. Kinerja karyawan pada STMIK Rosma Karawang sudah cukup baik dan agar ditingkatkan lagi terutama pada kuantitas kerja, yaitu melakukan pekerjaan sesuai dengan yang diperintahkan dan berupaya melakukan pekerjaan sesuai dengan prosedur dan mekanisme kerja yang ada, kehadiran karyawan tepat waktu di tempat kerja serta bekerja dengan waktu yang efektif dan efisien.

5. Mengoptimalkan motivasi karyawan STMIK Rosma Karawang, melalui program atau kebijakan yang berkaitan dengan kompetensi 
6. Mengoptimalkan motivasi karyawan STMIK Rosma Karawang, melalui program atau kebijakan yang berkaitan dengan kompensasi seperti kenaikan gaji secara rutin dan berkala, adanya special adjusment dalam proses kenaikan gaji yang dapat dilihat berdasarkan prestasi karyawan. Pemberian tunjangan, perbaikan fasilitas penunjang pekerjaan dan lain-lain.

7. Mengoptimalkan kinerja karyawan STMIK Rosma Karawang, melalui program atau kebijakan yang berkaitan dengan motivasi diantaranya dengan pemilihan pegawai berprestasi , menerapkan reward and punishment, dan lain-lain

8. Adanya kajian atau penelitian lebih lanjut tentang variabel lainnya yang mempengaruhi variabel motivasi karyawan STMIK Rosma Karawang, serta variabel lainnya yang mempengaruhi variabel kinerja karyawan STMIK Rosma Karawang sehingga diharapkan fungsi dan sistem manajemen dapat berjalan lebih optimal diantaranya variabel kepemimpinan, pengembangan karir, budaya organisasi, dan lain-lain.

\section{DAFTAR PUSTAKA}

Alma, Buchari 2007. Manajemen Pemasaran dan Pemasaran Jasa. Bandung : Alfabeta

Darodjat, Tubagus Achmad. 2015. Konsep-konsep Dasar Manajemen Personalia Masa Kini. Bandung: Rafika Aditama.

Harimisa, Margareta. E. 2013. Kepemimpinan dan Motivasi Kerja Pengaruhnya terhadap Produktivitas Kerja Pegawai di Kantor Camat Sario Kota Manado. Jurnal EMBA 2143 Vol.1 No.4 Desember 2013, Hal. 2143-2154. Fakultas Ekonomi dan Bisnis Jurusan Manajemen Universitas Sam Ratulangi Manado

Heidjrachman dan Suad Husnan. 2000. Manajemen Personalia., Edisi 4. Cetakan Kesembilan. Yogyakarta: BPFE

Marwansyah, 2014, Manajemen Sumber Daya Manusia, Edisi 3.Bandung: Penerbit Alfabeta

Mondy, R. Wayne. 2008. Manajemen Sumber Daya Manusia, Edisi 10. Jakarta : Penerbit Erlangga
Sastrohardiwiryo Siswanto. 2002. Manajemen Tenaga Kerja Indonesia,Pendekatan Administratif dan Operasional. Jakarta : Penerbit Bumi Aksara.

Sudarmanto. (2009). Kinerja dan Pengembangan Kompetensi SDM . Jogyakarta: Pustaka Pelajar.

Soeprihanto, John. 2009. Penilaian Kinerja dan Pengembangan Karyawan. Yogyakarta : BPFE Sugiyono. 2009, Metode Penelitian Administrasi, Bandung: Alfab 